WEBERIAN MODEL OF SOCIAL STRATIFICATION -A VIEWPOINT-

\section{Dr. Kailash Pyakuryal*}

In this paper, an attempt has been made to discuss the concept of social stratification according to the Weberian model. The first section deals with explaining the various concepts such as economic class, social status and political power (party). The second section discusses the inevitability of social stratification and finally, in the last portion, Karl Marx and Max Weber are compared with regards to their views on social stratification.

Social stratification has been viewed by Weber in three dimensions (Weber, 1947): economic class, social status, and political power (party). Each of these dimensions has its own stratification: the economic, represented by income and the goods and services which an individual possesses: the social, represented by the prestige and honor he enjoys: and the political, represented by the power he exercises. According to Weber's scheme, class, based on the economic order, would be no more than one aspect of the social structure (Stavenhagen, 1975). Power is the main element in this model. Power has been viewed as the chance of a man or of a number of men to realize their own will in a communal action even against the resistance of others who are participating in the action. Power gives social honor. Economic power is not identical with power because mere economic power and especially naked money power is by no means a recognized basis of social honor. Nor is power the only basis of social honor. Power, as well as honor, may be guaranteed by the legal order. But legal order is not the primary

* Dr.Kailash Pyakuryal is the Professor in Rural Sociology at the Central Department of Sociology and Anthropology, Tribhuvan University, Kirtipur, Kathmandu.

The author duly acknowledges the comments made on this article by Professor Chaitanya Mishra in its earlier version. source of power. It is rather an additional factor that enhances the chance to hold power or honor: but it cannot always secure them.

Weber understood law as a system that is effective because people orient their action to it. In addition, it is provided with an enforcement apparatus consisting of a staff of men. Weber was particularly interested in the factors and types of people that shape the law, as well as in the creation of law, especially natural law.

\section{Economy}

Weber understood economic action as instrumental to the peaceful exercise of the power of control which in its intended meaning is oriented towards meeting the demand for goods and services. His primary interest was in capitalism, which he dealt with in its relationship to the genesis of the modern state and the formation of state monopolies: in his opinion, monopolies originally promoted capitalism, but later on they hindered it. To Weber, the factory was --- regardless of prevailing economic order --- a workshop with a division of labor and a type of work oriented to machinery. It is especially important to Weber that the outcome of competition, in spite of chance and fate, leads to the actual selection of those who have the necessary personal qualifications in greater measure than other qualities such as devotion to superiors of demagogic talents. This is said without implying the value judgement that the victors in the competitive battle are for that reason more valuable from an ethical or some other point of view (Honigsheim, 1968).

\section{Status Groups and Classes}

Weber used the term "stand" (status group) to refer to such groups as junkers, industrialists, and German civil servants (Bendix, 1966). In imperial Germany, stand designated the social rank of an individual and of his group. This rank consciousness was a complex phenomenon. Weber emphasized that the collective actions of junkers as well as of farm workers could not be understood in economic terms alone. It also was necessary to analyze the ideas derived from the sub-culture of each group -- 
in Weber's terms, its "style of life" which interred into the evaluation of its economic interests.

The significance of this concept of stand or status groups becomes apparent in the contrast Weber made between it and class.

The term "class" refers to any group of people (who have the same typical chance for a supply of goods, external living conditions, and personal life experiences, insofar as this chance is determined by the power to dispose of goods or skills for the sake of income in a given economic order --. "class situation" is, in this sense, ultimately "market situation" (Bendix, 1966: Lasswell, 1965). For Weber, as for Marx, the basic condition of "class" lay in the unequal distribution of economic power and hence the unequal distribution of opportunity. But for Weber, this economic determination did not exhaust the condition of group formation. In contrast to the economically determined "class situation," "status situation" is designated as every typical component of the life fate of men that is determined by a specific, positive or negative, social estimator of honor ... In content, status honor is normally expressed by the fact that a specific style of life can be expected from all those who wish to belong to the circle. Linked with this expectation are restrictions on social intercourse (that is, intercourse which is not subservient to economic purposes). These restrictions may confine normal marriages within status circle (Krauss, 1976).

Stratification by status group goes hand in hand with a monopolization of ideal and material goods or opportunities. Besides the specific status honor, which always rests upon distance and exclusiveness, we find all kinds of material monopolies. Such honorific preferences may consist of privilege of wearing special costumes, of eating special dishes, of taboos to others, of carrying arms, etc. The decisive role of "style of life" in status "honor" means that status groups are the specific bearers of all conventions. Economic actions are oriented towards a rationally motivated adjustment of interests. In status order, men are grouped by their prestige and way of life. All actions based on the consideration of status are oriented to the feeling of the actors that they belong together. To safeguard status, men will oppose all suggestions that wealth as such is a valid basis of prestige. Otherwise, a rich man could claim more honors than one with distinguished family lineage and this would undermine the status honor.

Barber (1957) defined a stratified society as one in which the population has been separated into categories that are unequal in social evaluation. The greatest the inequality among categories or the less the likelihood of their becoming equal, the more highly stratified the society is said to be.

Weber's conception of status stratification consists of the division of society into distinct communities, separated by social distance and mutual exclusiveness. The epitome of a status stratified society and its most extreme case as described by Weber, is a society with a caste system (for example, Hindu society) (Weber, 1958).

The members of a "status group" interact with one another as a rule: each status group has its own set of conventions, laws, and rituals: each has its own "style of life," which Weber defined as a pattern of use of consumer goods. The observation of social strata as defined by Weber requires study of patterns of behavior and interaction rather than of abstracted qualities or properties of people.

Obviously, the more nearly a society reaches a caste system in its organization, the easier it is to study its patterns of social stratification as Weber defined them. As a society becomes more homogeneous in conventions, rituals, and style of life or less discriminating in association and marriage patterns, it becomes increasingly difficult to study its patterns of status stratification. In a completely homogeneous and undiscriminating society (if such can be imagined) there would, of course, be no status stratification at all.

Social stratification involves society as a system of hierarchical categories. Hierarchies may be formed for any of an indefinite number of referents or for any graded value. Barber defined a stratified society as one in which there are unequal categories of people. In contrast with Barber's categories, Weber posited communities. Weber defined stratification as the division of a society into distinct communities, which have 
varying assignments of "status honor" or prestige. Although each community has distinguishing characteristics, they are secondary to membership in the community as criteria for assigning persons to social strata. These two concepts require different techniques for empirical observations.

Michels (1962) believed that social classes, as they were found in the early nineteenth century, were a necessary evolutionary stage in social organization as it moved from a master-slave to a communistic stage. In the Master-slave State, the ascendant masters controlled the slaves' activities and literally possessed them as private property. In the ultimate communistic state, which Michales believed would be characterized by complete economic and political democracy, each man would be his own master. In the transitional period, the slaves had been freed but the unfortunate, the inept, and the inadequate, as a class, found themselves dominated by the fortunate, the shrewd, and the capable (Bogardus, 1960).

For Karl Marx, the important feature of social classes was their economic self-interest. He envisioned all history as the story of the struggle for subsistence and material goods. The revolution in methods of production of material goods had produced two quite divergent ways of securing subsistence: (1) owning the machines and factories and asking payment for ownership in the form of profit on goods sold; and (2) operating the machines, working in factories, and asking payment for labor in the form of wages from the owners. Marx felt that conflict between these two classes -- capitalists and workers -- was inevitable since both must draw their subsistence from the profit earned. The capitalist, Marx believed, had a definite upper hand as long as he could fix the price of goods produced, and also fix the workers' wages.

He thought that the day was bound to come when the competitive market and the greed of the capitalists would lead to a revolution of the workers. In this revolution, the workers would gain political control in order to confiscate the means of production. Then, as both owners and workers, they could themselves have control on income. Ultimately, the need for political government would wither away and the remaining worker-owner class would, in fact, constitute no class at all.

The independent criterion for class distinction in the Marxian two-class system is eminently clear. Stated simply, it is: does the person in question relate himself to the productive system as (1) an independent producer of goods who may, if he needs or wishes, employ others by purchasing their works; as (2) a worker whose manpower is for sale?

Wilfredo Pareto held that at any given period of time in every society there are two classes of elite persons--one in political power and the other out of political power. He defined elites as persons who possessed intelligence, character, skill, and high capabilities. He believed that the elite did not produce enough elite children to produce a continuous upper class, but that the lower classes produced elite children to replace the old elites. Instead of a succession of a communist society without class as Rodbertus and Marx predicted, Pareto and the fascists foresaw the continued existence of upper and lower classes with upper class-- or a fraction of it--always dominating the lower. Pareto did not believe in inherited aristocracy but that superior people--"natural aristocracy," as Thomas Jefferson put it-- as a class would always dominate inferior people as a class.

Michels (1962) further believed that the circulation occurred without need for a massive change in elites; that the "old" elite offset its natural tendency to decline in power by incorporating the rising elite persons into its organization.

The most remarkable difference in the conceptualization of social class in early industrial society between Weber and that of Marx, Pareto and Michels is that Weber denied the "community" of social class. For Weber, a class was a category of population with similar "life chances." By "life chances" Weber meant opportunities for acquiring or maintaining a characteristic range of material goods and life experiences. Weber contrasted "class" used in this sense with "status group" (which he did see as a real community with recognized prestige and "style of life," and "party"--. a power group struggling for domination) (Lasswell, 1965; Tumin, 1970). 
Weber further viewed status from two distinct concepts: (1) class status, and (2) social status.

Weber's concept of class status dealt primarily with the ability of the individual to control his economic environment, but he modified this definition by considering the individual's reaction to such ability or lack of it. Social status applies to a typically effective claim to positive or negative privilege with respect to social prestige so far as it rests on one or more of the following bases: (1) mode of living, (2) a formal process of education which may consist of empirical or rational training and the acquisition of the corresponding modes of life, or (3) on the prestige of birth or of an occupation (Lasswell, 1965).

Max Weber has been criticized by Oliver Cromwell Cox (Cox, 1970) when he writes, "Max Weber is not clear on class." One part of Weber's discussion is too much in outline form and another is almost an economic philosophy of class (political class). Class is conceived as a function of the market. Indeed, the author (Weber) speaks of "class position" as "market position." Weber recognizes many types of classes: "possessing or property class," "earning or income class," "social class" and subdivisions of these, but here class becomes a classification rather than a sociological concept.

\section{Is Social Stratification Inevitable?}

Inkeles maintains the following strata: ruling elite, the superior intelligentsia, the general intelligentsia, the workingclass aristocracy, the white-collar workers, the well-to-do peasants, the disadvantaged workers, and the forced-labor groups (Inkeles, 1950).

Davis and Moore (1945); Bernard (1957) and various others maintain the functional necessity of social stratification. Individuals have to be placed in different positions in the social structure. If the duties associated with the various positions were all equally pleasant to the human organism, all equally important to societal survival, and all equally competent in need of the same ability or talent, it would make no difference who got into which position, and the problem of social placement would be greatly reduced. But actually it does make a great difference who gets into which position, not only because some positions are inherently more agreeable than others, but also because some require special talents or training and some are functionally more important than others.

Also, it is essential that the duties of the positions be performed with the diligence that their importance requires. Inevitably, then, a society must have, first, some kind of rewards that can be used as inducements and, second, some way of distributing these rewards differentially according to positions. The rewards and their distribution become a part of the social order, and thus give rise to stratification. Social inequality is thus an unconsciously evolved device by which societies insure that the most important positions are conscientiously filled by the most qualified persons. Hence, every society, no matter how simple or complex, must differentiate persons in terms of both prestige and esteem and must, therefore, possess a certain amount of institutionalized inequality.

Where knowledge and skill accumulate, as they do in human society, specialization and therefore, differentiation seem inevitable. Insofar as stratification is a result of social differentiation then, there is not much scope for eliminating stratification. It can be concluded that some system of stratification is a functional requirement of societies.

\section{Marx and Weber Compared}

No one in the history of social thought has made the struggle between competing social and economic classes so central a feature of society and so dominant a source of social change as Karl Marx. The history of existing societies is the history of class struggles, according to Marx. According to Marx, classes develop on the basis of the different positions or roles which individuals fulfil in the productive scheme of a society. The key concepts for Marx are the modes of production such as agriculture, handicraft, industrialism, etc., and the relations of production--- the major levels of status in the economic enterprise. As Marx saw it, men in different relations to the means of production naturally have opposed interests. The capitalists have the control over the means of production. There 
are three more concepts in the Marxist approach to the study of stratification: (1) class consciousness, which refers to the consciousness of being exploited and deprived of the "surplus value," (2) class solidarity, which refers to the extent to which workers act together to achieve political and economic aims, and (3) class conflict, which refers to the unconscious or conscious and deliberate struggle between two classes when the workers become aware of the historic role and act collectively to improve their situation, and ultimately, to take over ownership of the instruments of production.

For Marx, under the "proper" circumstances, the workers would develop an awareness of their situation and would act collectively upon it. He also introduced the concept of "false consciousness" (Gidden, 1977; Tumin, 1967).

Weber agreed with certain fundamental features of Marxist thought, particularly with the crucial significance of the economic aspects of stratification. For Weber, as for Marx, control over property was a basic fact in the determination of the life-chances of an individual or a class. In contrast to Marx, however, Weber added to the economic dimension of stratification two other dimensions: power and prestige. Weber viewed property, power and prestige as three separate though interacting bases on which hierarchies are created in any society. Property differences generate classes; power differences generate status groupings or strata.

Marx and Weber differ on the question of how likely it is that members of the same economic class exercise united effort in seeking to achieve common purpose. Weber also differs from Marx about the probability of true class-consciousness and class struggle against the exploiting system.

Weber recognized that many kinds of class actions are possible, only some of which seek to change the basic forms of the prevailing system of property relations. Marx, too, showed this awareness when he spoke of workers acting with false consciousness, and acting in ways that fall short of trying to overthrow the existing system of property ownership.

Weber says explicitly that while economic classes do not normally constitute communities, status groups do, Status groups are formed on the basis of common amounts of socially ascribed prestige or honor. Usually, Weber says, status stands in sharp opposition to the pretensions of property. Both the propertied and propertyless can, and frequently do, belong to the same status group. However, along with Marx, Weber recognized the essential significance of property differences in the formation of status groups and in the ultimate hardening of the lines of distinction and privilege among them. He differed from Marx in the importance that he ascribed to status groups and, in the lesser likelihood, that he assigned to the development by members of an economic class of a sense of community and a commonly felt need for concerted action against the system as such.

The third form of association to which Weber gave prominence is the party. Party differed significantly from economic classes or status groups. Weber's emphasis was on the role of the political party as a separate dimension of the reward structure. It draws attention to an important issue; namely the relationship between class inequality and mass political parties designed to redress the balance of advantages in favor of the subordinate class (Parkin, 1976).

To sum up, Weber's approach is a view of society containing three kinds of social aggregations. Thus we have the economic focus of classes, the honor basis of status groups, and the power center of parties (Tumin, 1967).

Marxian model of stratification is a useful tool in the understanding of stratification more in a capitalist society where class formation is distinct with two distinct income groups, the rich and the poor, creating a class based social stratification. In such societies, conflicting class interests clash and new relationships are established. But Nepali society is a semi-feudal and semi colonial society where inequality and stratification are created by a combination of variables such as age, gender, income, ethnicity, caste and class. The society is more closed and social status is ascribed. Weberian model of social stratification thus fits better in contemporary Nepal in the understanding of social stratification. 


\section{REFERENCES}

Barber, Bernard 1957

Social Stratification, Comparative Analysis of Structure and Process. Harcourt, Brace and World, Inc., New York,

Bendix, Reinhard. Max Weber

1966 An Intellectual Portrait. Lowe and Brydone (printers), Ltd., London.

Cox, Oliver Cromwell

1970

Caste and Race -- A Study in Social Dynamics. Modern Reader Paper Back Series, New York.

Davis, Kingley and Wilbert Moore

1945 Some Principles of Social Stratification,

American Sociological Review 10 No. 2.

Emory, S. Bogardus

1960 The Development of Social Thought. Longman Green and Co., New York,

Giddens, Anthony

1977

Capitalism and Social Theory. Cambridge University Press, New York.

Honigsheim

1968

On Max Weber, Translated by Joan Rytina. The Free Press, New York.

Inkels, Alex 1950

"Stratification and Mobility in Society Union", American Sociological Review 15, 465-479

Krauss Irving

1976

Stratification, Class, and Conflict. The Free Press, New York.

Lasswell, Thomas E.

1965
Class and Stratum. Houghton Mifflin

Company, New York.
Michels, R.

1962

Political Parties: A Sociological Study of the Oligarchical Tendencies of Modern

Democracy, Free Press, New York.

Parkin, Frank

1976

Class Inequality and Political Order. Praeger Publishers, New York.

Stavenhagen, Rodolfo

1975 Social Classes in Agrarian Societies,

Translated by Judy Alder Hellman, Anchor

Press, New York.

Tumin, Melvin M.

1970

(ed.) Readings on Social Stratification.Prentice Hall, Inc., New Jersey.

Tumin, Melvin M.

1970 Social Stratification. Prentice Hall, Inc.

Englewood Cliffs, New Jersey.

Weber, Max

1958

From Max Weber: Essays in Sociology. M. M. Gerth and C. Wright Mills, Eds. Oxford Press, New York.

Weber, Max

1947

The Theory of Social and Economic Organization. Free Press, New York. 